\title{
More Homework and Less Play Makes Better ESL Pupils?
}

\author{
Parmjit Singh", ${ }^{1, *}$ Nadhrah Binti Ab Satar ${ }^{1}$, Kaarthy Supramaniam ${ }^{1}$, Teoh Sian Hoon ${ }^{1}$, \\ Geethanjali Narayanan', Gurnam Kaur Sidhu ${ }^{2}$ \\ ${ }^{1}$ Faculty of Education, University Teknologi MARA Selangor, Malaysia \\ ${ }^{2}$ Faculty of Education, SEGi University, Kota Damansara, Malaysia
}

Received January 19, 2020; Revised March 17, 2020; Accepted March 28, 2020

Copyright@2020 by authors, all rights reserved. Authors agree that this article remains permanently open access under the terms of the Creative Commons Attribution License 4.0 International License

\begin{abstract}
Homework has become an important part of pupils' and teachers' everyday lives in the Malaysian context. As pupils continue to display poor proficiency in English Language, completing homework has become an important after-school activity. Hence the aim of the study is to identify the types of homework assigned by English teachers and to examine the time spent in completing them. A total of 346 pupils from Year Four and Year Five (ages 10-11) and 14 fourteen teachers participated in this study. The mixed-method approach included a survey and an interview to measure the participants' views on the types of homework and time spent in completing them. The findings indicate that essay writing, reading and copying texts were the most common homework assigned whereas projects were the least. Also, Year Four and Year Five pupils spent approximately 39.2 minutes and 47.2 minutes respectively each day completing their homework. The interview data revealed that the teachers preferred to assign drill-based exercises and avoided projects due to time constraints. It is recommended that teachers place more importance on project-based assignments, and less on drills which promote rote learning.
\end{abstract}

Keywords Homework, ESL, Types of Homework, Time, Primary, Essay Writing, Rote Learning

\section{Introduction}

Teens think listening to music helps them concentrate. It doesn't. It relieves them of the boredom that concentration on homework induces.

Marilyn vos Savant

If homework, in Savant's perspective, induces boredom in young adults, what is more in the case of children? No doubt, homework is assigned to pupils as one of the primary strategies to enhance their classroom learning through reviewing, revising and reinforcing learning within a limited time (Parmjit, Gurnam and Chan, 2013; Painter, 2013). The assignment or task given by the teachers is to be completed by the pupils outside school hours (Cooper, 1989). This after-school task is perceived to be beneficial as it helps pupils to become independent learners. In fact, completing homework is said to provide opportunities for additional learning where pupils could reinforce their skills (Ohlenroth, 2011\& Warger, 2001). Cooper, Robinson and Patall (2006) attest that there is a significant relationship between the amount of homework completed and improvements in pupils' academic achievement. Parmjit, Gurnam, and Chan's (2013) concur as approximately $90 \%$ of parents in their study agreed that their children learned substantially from completing homework. They reported that children learned independently, improved their academic achievements and reinforced the learning that occurred in classrooms.

However, the previous studies failed to indicate if the children improved in their language learning skills. As language learning involves listening, speaking, reading and writing, it is unclear which components of language learning is most affected or how, as completing homework independently after school hours means teachers (and parents) would not be there to guide them. In English as Second Language context, the challenges on young learners is more pronounced as they need to have a working level of linguistic repertoire to comprehend and execute the tasks assigned, in other words, the declarative and procedural knowledge related to the target language.

\subsection{Theoretical Background}

Literature on acquisition of language informs that learners need procedural and declarative knowledge (Bates 2004; Ullman, 2001, 2004). For instance, Ullman's (2001, 
2004) Declarative and Procedural Model of Language illustrates that declarative and procedural memory support different components of language learning. Declarative memory is perceived as vital for learning and storing lexical item, which means the phonological and semantic representations of language learning are processed herein. Comparatively, Procedural memory is said to support the acquisition and storage of grammatical forms (e.g. English regular past tense). The implications of such theorizing on second language learning is profound as learners in ESL context may depend on their procedural memory system for learning and storing grammar knowledge. However, acquisition of certain grammar rules remains arbitrary, such as irregular word forms (e.g. sheep/ sheep, cat-cats) and regular past tense (e.g. Rice et al. 1998) that Ullman notes are acquired and stored by the declarative memory system. This means that ESL learners who are less proficient need closely guided instructions at least until they can retrieve and apply the correct grammar rules in their production. Until then, it cannot be assumed that everyone is equipped with appropriate declarative and procedural knowledge to complete an English language task on their own. The risk is that learners may get demotivated and lose interest if they deal with tasks that are challenging and beyond their ability. Worse, if there is no "more knowledgeable others", i.e. Vygotsky's Zone of Proximal Development, that could guide them in the home environment.

Cooper (2007) confirms that the amount and the type of homework should vary according to the child's developmental level and home circumstances. According to Cooper, homework can be classified according to amount, skill area, purpose, degree of choice for the students, completion dateline, degree of individualization and social context. Although most homework embodies several elements of different purposes, it can have an overall positive effect on pupils' level of achievement, improvement in educational skills, and social skills only when it is planned and designed properly (Haas, 2008). For instance, homework based on projects often involves various tasks where the output is either products, events or presentations. In ESL context, pupils who are already struggling to cope with language proficiency may find completing such types of homework more burdensome as they involve various modes and discourses. Besides that, completing projects as homework outside of school hours means lesser quality time to themselves despite being in informal learning environment (Schwalm and Tylek, 2012). Many deal with boredom and will most likely shun homework (Shumow, Schmidt \& Krackar, 2008). Hence it is pertinent to discover how much time pupils spend in completing their homework and if this improves their linguistic skills.

\subsection{Context of the Study}

In the local Malaysian context, the government has prioritized the teaching and learning of ESL as manifested in the well-documented Malaysian Education Blueprint, 2013-2015. At the end of their primary education, pupils are required to sit for a school-based assessment to gauge their academic achievement. Although the results of primary school assessments are not high-stake as all pupils go on to secondary education, it remains competitive as parents and school administrators refer to the results for selecting future schools and even careers. Comparatively, the secondary Malaysian Certificate of Education (Sijil Pelajaran Malaysia, SPM) is considered high-stake as students, parents and other stakeholders refer to it for employment or post-secondary education (Supramaniam \& Mohamad Nazer, 2016). In other words, Malaysian society in general view year-end academic results as evidence of their children's total sum of academic ability whether at the primary or secondary level of education.

As mentioned, the primary school assessment results are viewed by stakeholders as reflecting pupils' academic achievements, and in some cases, referred to for accepting pupils into certain types of secondary schools. For instance, pupils may apply to the prestigious Junior MARA colleges if they have excellent academic results. In this sense, the primary school assessment results remain high stake, and unfortunately, which has resulted in the phenomenon of "teaching to test" (Sofi Ali, 2003; Norris, 1993; Nutall, 1995a) rather than in promoting knowledge. Therefore, a lot of emphasis would be placed on drills and repetitions in teaching, which naturally extend to homework because immense pressure is put on teachers to show good results. A means to ensure success among low proficiency learners is through rote learning, pattern drillings, memorising or copying text.Sofi Ali (2003) reveals that pupils themselves may adopt repetition as a learning strategy to ensure that they could recall information easily during tests. He also attested that rote-learning approaches were prevalent in the Year Six examination classes. However, it remains unraveled if the practices are common in the Year Four and Year Five classes which are not considered "high stake". By focusing on Year Four and Year Five pupils in this study, the research raises questions of the types of homework given to learners, if they reflect Sofi Ali's "teaching for test" or otherwise despite the nation-wide call for student-centered twentieth century teaching approaches.

Arguably, some scholars insist that the practice of assigning homework regularly could encourage weak students to improve their knowledge and practice, and in the long run improve their level of literacy.It should also be structured and planned accordingly based on appropriate instructional and non-instructional practices (Cooper, 2007). In fact, when executing the holistic approach delineated in the Malaysian National Education Philosophy, teachers are expected to deliberate on the planning of teaching and learning practices in line with learning principles. Needless to say, the planning must match the 
students' cognitive readiness (Epstein et al., 1993) as different types of homework could have different effects on pupils. However, observing the types of rote teaching methods adopted by teachers (Lim as cited in Sofi Ali, 2003) and school foci that include extensive practices with past examination questions and probable questions in forthcoming examinations, the impact on pupils' literacy level is questionable. Furthermore, the exam-focused teaching approach is in congruent with the aim of the Malaysian Education Development Plan (MEDP) 2013-2015 that focuses on High Order Thinking Skills (HOTS). Pupils are expected to develop critical thinking and creativity to be able to compete internationally (NST 30, January 2014, p.7). Hypothetically, the types of homework assigned to pupils should foster the skills targeted in the MEDP policy.

This study examines the types of homework that are assigned by teachers in the ESL classrooms and determines whether they are in tandem with MEDP policies and global education reforms. This step is necessary as teachers have been given the opportunity to practice authentic and meaningful teaching and learning practices under the new syllabi standards of School-Based Assessment (SBA) introduced in 2010. SBA is designed to offer a holistic appraisal of students' academic achievements, and teachers have been urged to consider assigningoral reports, presentations, demonstrations, written assignments, and portfolios instead of relying on top-down summative year-end formal exams. It was perceived that the holistic appraisals and relevant homework could eventually reduce stakeholders' high expectations of the year-end examination results and boost pupils' motivation to learn.

The phenomenon of homework has been reported at a global level too. According to a report from the Organisation for Economic Co-operation and Development (OECD, 2012) which oversees the Programme for International Student Assessment (PISA) showed that in 2012, 15-year-old students in Malaysia spent an average of 4.8 hours a week on homework when compared to their peers in Singapore, Japan and Finland who spend 9.4 hours, 3.8 hours, and 2.4 hours respectively. Although previous studies have depicted a positive and significant relationship between the amount of time spent and individual performance (De Jong et al., 2000, Cooper et al., 2006; Trautwein, 2007; Trautwein et al., 2009), the PISA study revealed that the average number of hours that pupils spent completing their homework or other tasks assigned by their teachers seemed unrelated to the overall performance of their schools. Based on this finding, it is likely that factors like teacher quality and school organization have greater impact on a school's overall performance than homework.

The present study examined the time spent on ESL homework per day by 10-11-year old pupils whereas the PISA study was based on the duration of time spent by 15-year olds on their homework per week. As the PISA study was based on 15-year-olds, hypothetically one may expect pupils around the ages of 10-11 in Malaysia to spend less than 4.8 hours per week.Primary school pupils take at least six subjects, e.g. Bahasa Malaysia, English Language, Mathematics, Science, Local Studies and Islamic Education/Moral Education. Muslim pupils also attend religious classes after school. Additionally, they spend approximately an average of eight hours in school including engaging in after-school activities. This indicates that about two-thirds of their daily lives are spent at home (Parmjit et al., 2013). If each subject teacher assigns homework daily, the pupils have much to complete after school hours. Worse, each subject teacher do not collaborate or discuss their classroom practices or content, which means that each teacher may assign homework for their subject. Inevitably this may put too much pressure on the pupils, creating unnecessary stress and resentment. Worse, they may also lose interest in learning (Hsu, 2015 from Golgowski, The New York Daily Times).

Too much time spent completing homework also deprives pupils of quality playtime necessary to enhance their overall well-being. The effects of socializing and physical activities are well-documented in related literature but keeping them at their desks for improving their cognitive level could be detrimental to their overall health. The subtle implications of lack of physical activities have been evidenced in Poh, Jannah, Chong, Ruzita, Ismail and McCarthy (2011) which focused on age and gender-specific waist circumference for Malaysian children and adolescents aged 6.0 - 16.9 years old. Based on 16,203 participants across all regions of Malaysia, the researchers found that at the 90th percentile, Malaysian children starting at 10 years of age displayed characteristics of abdominal obesity. In other words, this precisely points to Year Four Pupils. Wafa, Hamzaid, Talib and Reilly (2013) study too concurs with Poh et al.'s (2011) that Malaysian children displayed very low 'moderate to vigorous physical activity' levels and very high levels of sedentary behaviour.

Therefore it is pertinent to answer the question of how much homework should be assigned in the ESL context where the objective is to learn the target language. Although the Ministry of Education (2004) emphasized that teachers must take into consideration the ability of pupils, the duration for completing the homework, the types and levels of difficulty before assigning homework, teachers continue to assign homework like copying from textbooks or workbooks. How far projects and portfolios are assigned remains unclear.

In view of this, this study investigated the types of homework assigned and the amount of time spent doing the homework among upper primary pupils in urban primary schools in Kuala Lumpur. The following questions were addressed: 1. What are the common types of ESL homework assigned by English teachers as perceived by pupils? 2. How much time is spent by pupils on doing ESL 
homework? 3. What are the views of the teachers on the assignment of ESL homework?

\section{Methodology}

This study adopted a mixed-method approach that utilized descriptive research design and structured interviews. The descriptive research design is based on a survey of 346 randomly selected pupils from primary 4 and primary 5 (10 and 11-year-old) in five primary schools around Kuala Lumpur. In terms of gender composition from these selected samples, $50.3 \%$ were male (174) and $49.7 \%$ were female (172). Whereas in terms of grade level composition, 144 pupils were from primary four (41.6\%) and 202 were from primary five $(58.4 \%)$.

In the survey, pupils were asked about the types of homework assigned by their teachers using a five item scale (e.g. "Enrichment Exercises", "Copying Texts" and "Group Projects") based on a study by Mark Bray (2006).Possible responses for each item were based on a 5 -point scale which ranged from strongly disagree (scored 1) to strongly agree (scored 5). Alpha reliability coefficient for the instrument used for the study was .805 .

Pupils were asked to indicate how much time they spent on ESL homework during a typical day, with possible responses ranging from 0 hour (no homework) to 2 hours and more. The approximate mean score on the time spent was computed using the fundamental frequency distribution mean formula of $\sum f x / \sum f$. The data solicited via the survey from the students were self-administered by the research team themselves. Two learning periods were required for the questionnaire to be filled by the pupil. Before distributing the questionnaire, the pupil had been clearly explained on the purpose of the study. The research team acknowledges the limitation of survey method in collecting data from young pupils, however, effort was taken to minimize the limitation. The researchers read each question aloud with each participating class to enhance the internal validity.

Further, the structured interviews were administered to fourteen ESL teachers (see Table 1 below) on the types of homework that they would assign to their pupils, their views on assigning homework that required pupils to copy from text, and whether these types of homework are effective in promoting pupils' language development. Additionally, the teachers were also queried on their insights on project-based homework.

Table 1. Demographic profile of the ESL primary teachers

\begin{tabular}{|c|c|c|c|c|c|}
\hline Name & Teaching Experience & Gender & Name & Teaching Experience & Gender \\
\hline Respondent 1 & 7 years & Female & Respondent 8 & 8 years & Male \\
\hline Respondent 2 & 5 years & Female & Respondent 9 & 5 years & Female \\
\hline Respondent 3 & 3 years & Female & Respondent 10 & 2 years & Female \\
\hline Respondent 4 & 13 years & Male & Respondent 11 & 11 years & Male \\
\hline Respondent 5 & 10 years & Male & Respondent 12 & 12 years & Female \\
\hline Respondent 6 & 5 years & Male & Respondent 13 & 4 years & Female \\
\hline Respondent 7 & 4 years & Female & Respondent 14 & 5 years & Female \\
\hline
\end{tabular}

Table 2. Types of ESL Homework Assigned by English Teachers

\begin{tabular}{|l|l|l|l|l|l|l|l|l|l|}
\hline No & Item & \multicolumn{2}{l|}{ Primary 4 } & \multicolumn{2}{l|}{ Primary 5} & \multicolumn{2}{l|}{ Overall } \\
\hline & & M & SD & M & SD & M & SD & \\
\hline 1 & Corrections & 3.12 & 1.05 & 3.24 & .88 & 3.19 & .97 & 5 \\
\hline 2 & Enrichment Exercises & 3.37 & 1.22 & 3.83 & 1.05 & 3.60 & 1.14 & 3 \\
\hline 3 & Remedial Exercises & 3.32 & 1.22 & 3.12 & 1.19 & 3.22 & 1.21 & 4 \\
\hline 4 & Spelling & 3.24 & 1.24 & 2.98 & 1.04 & 3.11 & 1.14 & 6 \\
\hline 5 & Copying Texts & 3.78 & 1.28 & 3.71 & .99 & 3.75 & 1.14 & 2 \\
\hline 6 & Individual Projects & 2.80 & 1.23 & 2.66 & 1.16 & 2.73 & 1.20 & 8 \\
\hline 7 & Group Projects & 3.11 & 1.13 & 2.74 & 1.22 & 2.93 & 1.18 & 7 \\
\hline 8 & Essay Writing and Reading & 3.71 & 1.28 & 3.91 & 1.06 & 3.81 & 1.17 & 1 \\
\hline
\end{tabular}

(Scales from 1-strongly disagree, 2-disagree, 3 -somewhat agree, 4-agree, to 5-strongly agree) 


\section{Findings of the Study}

The first section investigated the types of ESL school homework assigned by teachers, followed by the amount of time pupils spent in doing ESL homework.

\subsection{Types of ESL Homework Assigned by English Teachers}

Table 2 depicts the descriptive statistics of the types of ESL homework assigned by English teachers to Primary 4 and Primary 5 pupils.

For Primary 4, the most common type of ESL homework assigned by teachers is Copying Texts $(\mathrm{M}=3.78, \mathrm{SD}=1.28)$ followed by Essay Writing and Reading ( $M=3.71$, $\mathrm{SD}=1.28)$ while the least common is Individual Projects $(\mathrm{M}=2.80, \mathrm{SD}=1.23)$. The other items ranged from mean scores of 3.11 to 3.71. As for Primary 5, Essay Writing and Reading was the most common type of homework assigned with a mean of $3.91(\mathrm{SD}=1.06)$ followed by Enrichment Exercises $(\mathrm{M}=3$. 38, $\mathrm{SD}=1.05)$ and Copying Texts $(\mathrm{M}=3.71, \mathrm{SD}=.99)$. Similar to Primary 4, Individual Projects and Group Projects recorded the lowest mean scores of $2.66(\mathrm{SD}=1.16)$ and $2.74(\mathrm{SD}=1.22)$ respectively. The rest of the items ranged from mean scores of 2.98 to 3.24. On an overall basis, Essay Writing and Reading recorded the highest mean score of $3.81 \quad(\mathrm{SD}=1.17)$ followed by Copying Texts $(\mathrm{M}=3.75, \mathrm{SD}=1.14)$ while Individual and Group Projects recorded the lowest mean scores of $2.73(\mathrm{SD}=1.20)$ and $2.93(\mathrm{SD}=1.18)$ respectively. The other items recorded mean scores ranging from 3.11 to 3.60 .

Additionally, the qualitative data gathered from the interviews revealed that Respondent 3, Respondent 4 and Respondent 6 assigned writing-based exercises to their pupils:

I do not usually assign homework to them but if I do, I'd give them writing-based exercises. (Respondent 3 )

I usually assign them essay writing. (Respondent 4)

I'd give them writing exercises as homework that is based on stimuli such as graphs, pictures and texts. (Respondent 6)

Two other teachers, Respondent 1 and Respondent 2 claimed that they preferred to assign grammar drills to their pupils:

I usually assign, well, drilling exercises on tenses and verbs to the pupils. (Respondent 1)

I always give grammar exercise drills to my pupils. (Respondent 2)

Other responses included guided homework and exercises from activity books:

I would assign them guided homework such as comprehension questions, constructing sentences, essay and grammar. (Respondent 5)

I would give them activity books to complete. (Respondent 7)
Furthermore, the teachers were also inquired on what they perceived their ESL colleagues assigned as homework to the pupils. The responses indicated that the majority of the respondents agreed that their colleagues would assign writing exercises, as mentioned by Respondent 1 , Respondent 2, Respondent 3, Respondent 6, and Respondent 7:

I think they usually assign the pupils to make sentences. Meaning, well, repetitive sentence writing. (Respondent 1)

I guess...making simple and compound sentences. (Respondent 2)

Writing exercises as well I guess. (Respondent 3 )

I suppose it's the same like what I'm doing (Respondent 6) (as shown previously, Respondent 6 stated that she would assign writing exercises as homework.)

They would assign writing tasks. (Respondent 7)

Only Respondent 4 stated that her colleagues would assign grammar drills instead of writing. Respondent 5 stated both - grammar and writing.

Usually they love to give grammar drills as homework. (Respondent 4)

They would assign grammar and writing. (Respondent 5)

Based on the findings from the qualitative data, it can be said that the findings correlate with the quantitative data where the teachers were found to be assigning writing-based activities as homework to their pupils.

\subsection{ESL Teachers' Perception on Drilling, Copying Texts and Project-Based ESL Homework}

The quantitative findings depicted that teachers often assigned drills and copying texts to the pupils and fewer project-based homework. Respondent 1, Respondent 2, Respondent 4 and Respondent 12 unanimously agreed that they gave instructions for both types of assignments especially drills:

I agree in assigning such tasks. This is because it will improve them as practice makes perfect. (Respondent 1) Yes, I agree in giving those types of homework. It helps in recapping the lesson taught. (Respondent 2)

I totally agree in giving these types of homework. I mean, it makes the job easy. (Respondent 4)

I assign all types of homework from time to time however due to pupils' low mastery of English language, easier to assign Copying text......easy to mark. (Respondent 12)

Although Respondent 5 and Respondent 6 concurred with the rest of their colleagues about assigning drills, they were against giving out assignments that involved copying texts. Respondent 6 revealed why other teachers preferred assigning copying texts as homework:

Copying text not quite (agreeable) but drilling yes especially constant drills on the type of format for exams. Our system is exam-oriented. (Respondent 5) 
I do not prefer assigning copying texts. As for drilling, it only works for UPSR (Primary School Examination). But other teachers still assign both maybe because it is easier for them - they don't have to prepare materials. (Respondent 6)

I know many senior teachers assign copying text as the most common type of homework, this is because it's easier to mark. (Respondent 10)

However, Respondent 3 and Respondent 7 completely disagreed on assigning both drills and copying of texts as homework:

I disagree in assigning such tasks. However, I know some of the English teachers do as such. Maybe because that our education system emphasizes exams. (Respondent 3)

Giving homework relying on copying of text is a disgrace. How are we to improve the standard of English language among our pupils? (Respondent 13)

I totally disagree. I won't do it but I can't say the same for others. Other teachers still assign maybe because it's easy for them. (Respondent 7)

The respondents were then asked on their perception regarding the effectiveness of drilling and copying texts in improving language development among pupils. Although two (Respondent 1 and Respondent 2) of the seven respondents believed that it is effective, the others either disagreed or claimed that it only helped with one aspect of language learning.

These types of homework limit the pupils' vocabulary and creativity. (Respondent 3 ).

I do not see this as being effective for pupils' language development. (Respondent 4).

Not so effective as it only trains the pupils to be familiar with the exam format. (Respondent 5).

It only develops their writing skill. (Respondent 7)"
Besides inquiring the ESL teachers' views on drills and copying texts as homework, the researchers also focused on the teachers' views relating to projects assigned as homework. Respondent R6YOE5 claimed that she had attempted to assign such homework to her pupils and discovered that she and the pupils found it to be enjoyable. However, she added that other teachers may not do so as they may be more focused on developing their pupils' basic language skills. This claim is supported by the other teachers:

Projects are too time consuming (Respondent 1, Respondent 2, Respondent 5).

Pupils lack the basic language skills (Respondent 1, Respondent 7).

Pupils still need guidance and step-by-step instruction and there are too limited sources at home (Respondent 3)

There is the lack of cooperation between pupils and some of them have attitude problems (Respondent 4).

\subsection{Time Spent by Primary School Pupils in Doing Their ESL Homework}

This section details the amount of time spent by pupils per day in completing their ESL homework as assigned by their school teachers. Table 3 shows the frequency distribution on the amount of time spent per day by primary 4 and primary 5 pupils in completing their assigned ESL homework. It shows that $29.9 \%(n=43)$ of the primary 4 pupils spent 15 to 30 minutes in completing their ESL homework while $68.8 \%(n=99)$ of them spent 30 minutes to an hour. From the estimation of time spent on doing homework, it can be concluded that primary 4 pupils spent approximately 39.2 minutes in doing their ESL homework per day.

Table 3. Amount of Time Spent per-day by Pupils in Completing their ESL Homework

\begin{tabular}{|c|c|c|c|c|c|}
\hline \multirow[t]{2}{*}{ Time } & \multirow{2}{*}{$\frac{\mathrm{x}}{\mathrm{hr}}$} & \multicolumn{2}{|c|}{ Primary 4} & \multicolumn{2}{|c|}{ Primary 5} \\
\hline & & $\mathrm{N}\left(f_{1}\right)$ & $\%$ & $\mathrm{~N}\left(f_{2}\right)$ & $\%$ \\
\hline $\begin{array}{l}\text { No homework } \\
15 \text { minutes to less than } 30 \text { minutes }\end{array}$ & $\begin{array}{ll}0 \\
0.375\end{array}$ & $\begin{array}{l}0 \\
43 \\
\end{array}$ & $\begin{array}{l}0 \\
29.9 \\
\end{array}$ & $\begin{array}{l}0 \\
12 \\
\end{array}$ & $\begin{array}{l}0 \\
5.9 \\
\end{array}$ \\
\hline 30 minutes to less than 1 hour & 0.75 & 99 & 68.8 & 174 & 86.2 \\
\hline $\begin{array}{l}1 \text { to } 2 \text { hours } \\
\text { More than } 2 \text { hrs }\end{array}$ & 1.5 & $\begin{array}{l}2 \\
0 \\
\end{array}$ & 1.4 & $\begin{array}{l}16 \\
0\end{array}$ & $\begin{array}{l}7.9 \\
0 \\
\end{array}$ \\
\hline Total $\left(\sum f\right)$ & & 144 & 100 & 202 & 100 \\
\hline
\end{tabular}

In estimating the time spent by pupils, the approximate formula used is as follows:

$$
\text { mean }=\frac{\sum f x}{\sum f}
$$

Estimating the time spent by pupils on ESL homework:

$$
\text { Year } 4=\frac{(43 \times .0 .375 \mathrm{hr})+(99 \times 0.75 \mathrm{hr})+(2 \times 1.5 \mathrm{hr})}{144}=\frac{93.375}{144}=0.654 \mathrm{hr}=39.2 \text { minutes }
$$




$$
\text { Year } 5=\frac{(12 \times 0.375 \mathrm{hr})+(174 \times 0.75)+(16 \times 1.5)}{202}=\frac{159.0}{202}=0.787 \mathrm{hr}=47.2 \text { minutes }
$$

Table 4. Overall approximate time spent per-day on ESL homework by Primary 4 and 5 pupils

\begin{tabular}{|c|c|c|c|}
\hline Time & $\mathrm{x}$ & $\mathrm{n}$ & $\%$ \\
\hline $\begin{array}{l}15 \text { minutes to less than } 30 \text { minutes } \\
30 \text { minutes to less than } 1 \text { hour }\end{array}$ & $\begin{array}{c}0.375 \\
0.75 \\
\end{array}$ & $\begin{array}{c}55 \\
273 \\
\end{array}$ & $\begin{array}{l}15.9 \% \\
78.9 \%\end{array}$ \\
\hline 1 to 2 hour & 1.5 & 18 & $5.2 \%$ \\
\hline Total & & 346 & $100 \%$ \\
\hline
\end{tabular}

From the total of 202 pupils from primary 5, 86.2\% (n $=174$ ) of them spent 30 minutes to 1 hour on their ESL homework, followed by $7.9 \%(n=16)$ between 1 to 2 hours. On the other hand, $5.9 \%(\mathrm{n}=12)$ pupils answered that they spent between 15 to 30 minutes completing their ESL homework. Thus from the table 3 , we can conclude that the average time spent on doing homework among primary 5 pupils is 0.787 hour or 47.2 minutes. It shows that primary 5 pupils spent more time completing their ESL homework compared to Primary 4 pupils (39.2 minutes). Based on this estimation, it can be concluded that the Primary 5 pupils spent approximately one eighth of an hour more than their Primary 4 counterparts in completing their ESL homework.

Estimation of Overall Time Spent by Pupils:

$=(55 \times 0.375)+(273 \times 0.75)+(18 \times 1.5)=252.375=0.729 \mathrm{hr}=$ 43.7 Minutes

Table 4 shows the overall time spent by pupils per-day in doing their ESL homework as assigned by teachers.It depicts that $78.9 \%(n=273)$ of the respondents answered 30 minutes to one hour as the time spent by them on doing the ESL homework. This is followed by $15.9 \%(\mathrm{n}=55)$ spending between 15 to 30 minutes and $5.2 \% \quad(n=18)$ between 1-2 hours. The estimate average times computed on the time spent by upper primary pupils in doing their ESL homework as assigned by their teachers is 43.7 minutes per-day.

\section{Discussion and Conclusions}

The purpose of this study is to gain insights into the types of ESL homework and duration of time spent in completing them. The analysis showed that primary 4 pupils copied texts (mean=3.78) the most as it was the most common type of homework assigned by their teachers in their ESL class. This is followed by Essay Writing and Reading $(\mathrm{M}=3.71, \mathrm{SD}=1.28)$. In contrast, the least common type of homework assigned is projects, whether individually or in groups. Primary 5 pupils mainly completed Essay Writing and Reading (mean= 3.91), Enrichment Exercises $(\mathrm{M}=3.83, \mathrm{SD}=1.05)$ and Copying Texts $(M=3.71, S D=.99)$. They attempted projects the least. A probable explanation for the emphasis on essay writing and reading among primary 5 pupils is that they would be sitting for the national examination (UPSR) in Primary 6 , where they would be tested on both skills.

One of the key findings of the study is that teachers mainly assigned copying texts as homework and projects the least, regardless of whether it is to be completed individually or in groups. Teachers' preference for copying texts seem to contradict findings in related research that project based assignments are suitable for learning as it involves formative assessment techniques that guide pupils to think critically, reflect and demonstrate their ideas (Chappuis \& Chappuis, 2008; Harlen, 2007; Scherer, 2007). Even at the primary level, pupils could be engaged in active participation in the classrooms (Hamm \& Adams, 2009; Stiggins \& Chappuis, 2006). Hence teachers could focus on assigning project based homework for their pupils and apply formative assessment techniques that may create learning opportunities and enhance the effectiveness of teaching and learning in the ESL classrooms.

As mentioned earlier, there is a greater emphasis on pupils merely copying from textbooks. This type of homework involves limited applications of thinking skills and could be considered as a sheer waste of time as more effective tasks could be assigned for language learning. It is important for teachers to assign homework based on a wide spectrum of thinking such as those that involve higher order thinking skills, and problem based approaches. These tasks promote students' active learning rather than rote learning which can bring positive impacts on pupils' academic performance (CCL, 2009). It is crucial to consider Anderson's (1999) taxonomy of Cognitive (Knowledge), Affective (Attitudes) and Psychomotor domains when designing homework especially for the ESL classroom as different pupils have different language learning abilities.

In terms of time spent by pupils in completing their ESL homework, the findings revealed that on the average, primary pupils involved in this study spent almost 43.7 minutes ( 0.729 hour), which is approximately 3.645 hours for a 5-day week. The results seem to be congruent with research done by Gregg (2004) that Malaysian pupils spent an average of 3.8 hours per day on homework. This is based on pupils' time spent on all their school subjects (e.g. Mathematics, Science, Bahasa Malaysia, Islamic Education or Moral Education and Local Studies). The questions that still persist are how much is allotted for each 
subject, and whether the time spent is effective enough to cater to their learning needs. Also, Skaggs (2007) and Cooper et al. (2006) warn that homework overload could cause emotionally fatigue and loss of interest in the academic materials, which may put some pupils at risk of resisting academic work or worse, dropping out of school. This finding concurred with parent's complaints on too much time spent in doing homework which somewhat jeopardize their family time (News Straight Times, 2017). This report supports the claim that 'homework is not necessarily the way to a student's success' (News Straight Times, April 13, 2017). Bowman (2016) study which is based on 7000 students (average age of 13) revealed that students resisted completing homework when it took too long to complete. It also did not significantly impact test scores.

In conclusion, this study shows that the ESL teachers in primary schools either lacked knowledge of or disregarded the implications of assigning specific types of homework, and the duration of time it took for their pupils to complete them. It does not matter how much homework is assigned but the quality of ESL homework which may lead to pupils' improvement. Therefore, teachers should carefully design ESL homework to promote effective learning among Year Four and Year Five pupils who will be completing their primary education in Year Six. These pupils are basically in their 'critical period' of learning a second language and ESL teachers ought to carefully consider engaging them in authentic learning during this period as recommended by sociocognitive theorists. Indeed, completing projects could benefit pupils more than copying texts as the cognitive processes involved in completing them could positively influence their self-motivation in language learning. The findings in this study could inform English Language practitioners in Malaysia that prolonged time in completing homework does not guarantee increase in literacy level.

\section{REFERENCES}

[1] Anderson, L. W. (1999). Rethinking Bloom's Taxonomy: Implications for Testing and Assessment. US Department of Education. Educational Resources Information Center.

[2] Bates, E. A. (2004). Explaining and interpreting deficits in language development across clinical groups. Where do we go from here? Brain and language, 88(2), 248-253.

[3] Blazer, C. (2009). Literature Review: Homework. Paper Submitted for the Research Services of the Office of Assessment, Research, and Data Analysis, Miami-Dade County Public Schools, Miami, FL.

[4] Bowman, J. D. (2016). Why Students Don't Do Their Homework-And What You Can Do About It. Retrieved on 18th of December, 2019 from https://www.teachthought.co $\mathrm{m} /$ pedagogy/why-students-dont-do-their-homework-and-w hat-you-can-do-about-it/

[5] Bray, M. (2006). Private Supplementary Tutoring: Comparative Perspectives on patterns and Implications. Compare: A Journal of Comparative Education, 36 (4), 515-530.

[6] Brewster, C., Fager, J. (2000). Increasing Student Engagement and Motivation: From Time-on-Task to Homework. Northwest Regional Educational Laboratory.

[7] Canadian Council on Learning (CCL). (2009). A Systematic Review of Literature Examining the Impact of Homework on Academic Achievement.

[8] Carr-Gregg, M. (2004). Office for Standards in Education (Ofstead UK). (1997). Homework Learning from Practice, Summary of Findings from the Ofstead Research Study, UK: Ofstead.

[9] Chappuis, S., Chappuis, J. (2008). The Best Value in Formative Assessment. Educational Leadership, 65 4, 14-19.

[10] Cooper, H. (1989). Synthesis of Research on Homework. Educational Leadership, 3, 85-91.

[11] Cooper, H., Robinson, J. C., Patall, E. A. (2006). Does Homework Improve Academic Achievement - A Synthesis of Research, 1987-2004. Review of Educational Research, 76. 1-62.

[12] Cooper, H. (2007). The battle over homework: Common ground for administrators, teachers, and parents. Thousand Oaks, CA: Corwin Press.

[13] Daily Express (2017). Base homework time on quality, not number of hours. Retrieved on 11th December, 2019 from http://www.dailyexpress.com.my/read.cfm?NewsID=2615

[14] De Jong, R., Westerhof, K. J., Creemers, B. P. M. (2000). Homework and Student Math Achievement in Junior High Schools. Educational Research and Evaluation, 6, 130-157.

[15] Golgowski, N. (2015). Parents Outraged after Manhattan School Principal Dumps Homework for More Playtime. New York Daily News. Retrieved on the 11th of November 2019 from http://www.nydailynews.com/new-york/outrage -nyc-principal-dumps-homework-play-time-article- 1.2140 265

[16] Hamm, M., Adams, D. (2009). Activating Assessment for all Pupils: Innovative Activities, Lesson Plans, and Informative Assessment. united Kingdom: Rowman \& Littlefield Education.

[17] Hamzah, M. O., Sinnasamy, P. (2009). Between the Ideal and Reality: Teachers' Perception of the Implementation of School-Based Oral English Assessment. The English Teacher, 38, 13-29,

[18] Harlen, W. (2007). Formative Classroom Assessment in Science and Mathematics. McMillan, J. H. (Eds). Formative Classroom Assessment: Theory into Practice, 116-135. New York: Teachers College Press.

[19] McPherson, F. (2005). Homework - Is It Worth It? Retrieved on 4th December, 2019 from http://www.memory-key.com/Parents/ homework.htm.

[20] Ministry of Education. (2004). "Surat Pekeliling Ikhtisas Bil. 
12/2004. Garis Panduan Umum Pemberian Kerja Rumah Kepada Murid Sekolah.”

[21] Moorman, C., \& Haller, T. (2006a). Taking a Stand Against Homework. Retrieved on 18th of September, 2019 from http://www.janebluestein. com/articles/homework.html.

[22] News Straight Times (2017). Can homework determine a student's success? Retrieved on 12th November, 2019 from https://www.nst.com.my/opinion/letters/2017/04/229969/c an-homework-determine-students-success

[23] Ohlenroth, P. (2011). Homework. Retrieved on 19th November, 2019 from http://social.jrank.org/pages/318/Ho mework.html

[24] Parmjit, S., Gurnam, K. S., Chan, Y. F. (2013). Malaysian Parents' Practices and Perspectives on the Organization of School Homework. Social Sciences \& Humanities. 21 (3). 1019-1037.

[25] Painter, L. (2003). Homework. Oxford: Oxford University Press.

[26] Poh, B. K., Jannah, A. N., Chong, L. K., Ruzita, A. T., Ismail, M. N., \& McCarthy, D. (2011). Waist circumference percentile curves for Malaysian children and adolescents aged 6.0-16.9 years. International Journal of Pediatric Obesity, 6(3-4), 229-235.

[27] Scherer, M. (2007). Reclaiming Testing. Educational Leadership, 63(3), 9-13.

[28] Schwalm, J., Tylek, K. S. (2012). Systemwide Implementation of Project-Based Learning: The Philadelphia Approach. After school Matters. 15, 1-8.

[29] Skaggs, A. M. N. (2007). Homework: A Nightly Ritual Beginning in the Elementary Grades. Paper Submitted for the Degree of Master of Science in Education, Dominican University of California, San Rafael, CA.

[30] Stiggins, R., Chappuis, J. (2006). What a Difference a Word Makes. Journal of Staff Development, 27 (1), 10-14.

[31] Supramaniam, K. \& Mohamad Nazer, A. (2016). Two Rabbits in a Hat: Comparison of SPM English Language and IGCSE English as Second Language High-Stakes Tests. In de Mello, G. \& Husin, M.S. (Eds). Proceedings of National Conference of Research on Language Education (pp. 218-226). Melaka, Malaysia: UiTM

[32] Trautwein, U. (2007). The Homework-Achievement Relation Reconsidered: Differentiating Homework Time, Homework Frequency, and Homework Effort. Learning and Instruction, 17, 372-388.

[33] Trautwein, U., Schnyder, I., Niggli, A., Neumann, M., Ludtke, O. (2009). Chameleon Effects in Homework Research: The Homework-Achievement Association Depends on the Measures Used and the Level of Analysis Chosen. Contemporary Educational Psychology, 34, 77-88.

[34] Ullman, M. T. (2001). The declarative/procedural model of lexicon and grammar. Journal of psycholinguistic research, 30(1), 37-69.

[35] Wafa, S. W., Hamzaid, H., Talib, R. A., \& Reilly, J. J. (2013). Objectively measured habitual physical activity and sedentary behaviour in obese and non-obese Malaysian children. Journal of tropical pediatrics, 60(2), 161-163.
[36] Warger, C. (2001). Five Homework Strategies for Teaching Pupils with Disabilities. Retrieved on 15th of August, 2019 from http://files.eric.ed.gov/fulltext/ED452628.pdf 